\title{
Students, blood and teeth
}

We write this Editorial just after the Halloween festivities, so perhaps the title is timely. The importance of maintaining standards in undergraduate otolaryngology training is well recognised within our specialty. ${ }^{1,2}$ Unfortunately, despite ENT complaints being common in both primary and secondary care settings, the amount of time allotted to ENT teaching in the undergraduate curriculum is frequently woefully brief. Thus, it is important to ensure that any assessment of undergraduate student ability is robust. Woods and colleagues assessed the utility of both short answer questions and an objective structured clinical examination in a cohort of medical students. ${ }^{3}$ They found that both assessments were valid and reliable, and enhanced the undergraduate course by driving learning across different domains of competency.

The increasing use of anticoagulant medications is a feature of modern medicine. Knowledge of the different anticoagulant medications is important in the safe management of both emergency and elective patients. In a previous article, Biggs and colleagues produced a useful treatment algorithm for anticoagulant and antiplatelet therapy in epistaxis patients. ${ }^{4}$ New drugs are being introduced to the market with great frequency, and it is sometimes difficult to ascertain whether individual patients are on anticoagulants or not. The same group of authors have updated their original review with a guide to new anticoagulant medications for ENT surgeons. ${ }^{5}$ It is significant that most of the new antiplatelet drugs, such as apixaban and dabigatran, are irreversible in their actions.

An increasing amount of upper aerodigestive tract surgery is being undertaken endoscopically, particularly laser resection of laryngeal malignancy. ${ }^{6}$ Access in these cases is made more difficult (or impossible) by prominent incisor teeth, micrognathia or trismus. Damage to teeth may occur, and this is a frequent source of complaint and litigation. Butterworth and colleagues describe two cases in which elective dental extraction and replacement with an osseointegrated dental implant facilitated endoscopic surgery (performed for a pharyngeal pouch and glottic carcinoma). ${ }^{7}$ This method of osseointegrated treatment employed to overcome dental issues during transoral laryngeal surgery has not been previously described. It is interesting, however, that an account of dental extraction and re-implantation of the same teeth was described in The Journal of Laryngology \& Otology in 1994, to address similar issues. ${ }^{8}$

Finally, we would like to thank all of our colleagues at The Journal for their tireless work during 2015. We also thank our colleagues at Cambridge University Press for their support and partnership. Our Editorial Board continue to work hard in order to maintain a vigorous peer review system. We hope that our readers have enjoyed reading The Journal articles over the past year and have valued from the increasing educational content of our website. We wish all our readers a successful 2016.

\section{ROBIN YOUNGS EDWARD FISHER Senior Editors}

\section{References}

1 Mirza A, McClelland L, Daniel M, Jones N. The ENT emergency clinic: does senior input matter? J Laryngol Otol 2013;127:15-19

2 Löfgren E, Alikoski S, Hannula S, Sorri M, Alho O-P. Use of real patients in teaching ENT diseases to undergraduate students and its effects on patient satisfaction: cross-sectional survey. J Laryngol Otol 2015;129:666-9

3 Woods R, Subramaniam T, Patterson A, Hennessy M, Timon C. Validation and evaluation of new assessments for the otolaryngology undergraduate medical clerkship. J Laryngol Otol 2015;129: 1228-33

4 Biggs TC, Baruah P, Mainwaring J, Harries PG, Salib RJ. Treatment algorithm for oral anticoagulant and antiplatelet therapy in epistaxis patients. J Laryngol Otol 2013;127:483-8

5 Bajalan M, Biggs TC, Mainwaring J, Jayaram S. A guide to new anticoagulant medications for ENT surgeons. J Laryngol Otol 2015;129:1167-73

6 O'Hara J, Markey A, Homer JJ. Transoral laser surgery versus radiotherapy for tumour stage $1 \mathrm{a}$ or $1 \mathrm{~b}$ glottic squamous cell carcinoma: systematic review of local control outcomes. J Laryngol Otol 2013;127:732-8

7 Butterworth CJ, Lancaster J, Shah HS. Elective dental extractions and osseointegrated implant replacement to facilitate transoral endoscopic ENT surgical procedures. J Laryngol Otol 2015; 129:1234-37

8 Wareing MJ, Fisher EW, Manning RH, Gray RF, Lamb WT. The extraction and re-implantation of teeth for the difficult laryngoscopy. J Laryngol Otol 1994;108:44-5 